\title{
Product Differentiation and Intra-Industrial Trade: Quantitative Assessment in the Case of Tunisia
}

\author{
Bel Hadj Tarek \\ Faculty of Economics and Managements of Sfax, Tunisia \\ belhaj.tarek@laposte.net
}

\begin{abstract}
This article tries to analyze the extent of product differentiation in the Tunisian's context, by relying on an investigation derived at a sufficiently disaggregated level of sectors. In the first section, we tend to expose the relationship between market structure, product differentiation and intra-industrial trade. Then, we reexamine in the second section some operational proxies of products variety that were previously analyzed by the empirical literature. In the third section, we tend to appreciate the strength of products differentiation in the specific case of Tunisia and in 8 different sectors.
\end{abstract}

Keywords: product differentiation, horizontal differentiation, intra-industrial trade

\section{Introduction}

Market structure, product differentiation and intra-industrial trade: In order to apprehend the concept relating to the product differentiation we will analyze in what follows the contributions of the endogenous theory of growth based on the innovation as well as the new theories of international trade.

Market structure and innovation: Throughout the economic literature, link between industrial market structure and investments in R\&D or innovations has powerfully attracted attention. In fact, an important part of economic studies has extremely discussed the impact of competition's intensity on the incentives of innovative efforts. In his predecessor initiative, Schumpeter (1942) was an original partisan of the monopole's alternative. At this level, Schumpeter postulates that an important part of market, promoted by the predominance of monopolistic competition, represents a decisive factor to encourage firms to innovate. Those advantages reflected by a greater part of market, allow to share fixed costs of R\&D among a greater number of products variety, enhance the funding to a favorite markets, achieve an important economies of scale and finally permit to firms that has a most important size and most diversified to explorer the new discoveries. In this context, competition in one market leads to competition in a different market with the emergence of a new cheaper product that incorporates a more important fixed costs and insignificant marginal costs. In others words, imperfect competition leads to important market parts under the presence of huge entry barriers explicated in turn by inability to pursue the speed of innovations. In this later case, market's parts depend on intellectual proprieties. In according to Schumpeterian dynamics, the attempts of learning are originated from large firms that are more able to innovate and improve their productivity. This is plausibly explicated by the economies of scale, the availability of internal resources in the case of imperfect markets and /or uncertainty, and synergies between the technological, productive, marketing and distribution's activities. More recently, Link (1981) has explored these arguments and has showed that the rate of return of R\&D is positively associated with the market's size. In the same line of literature, Cohen and Klepper (1996) supported the argument according to that, as large firms produce a greater output, they are more able to apply the results of $R \& D$ to more range of products and process and so to share their costs. However, a contradictory theoretical developments has been elaborated by Griliches (1980) and Wang and Tsai (2003) indicating the absence of any effective association between the R\&D and the size of firms, that allow in turn to reject the Schumpeterian hypothesis. Beside, Arrow (1962) established a reversed supposition by putting forward the advantages of competitive structure revealed by the inability to appropriate the incomes associated with the efforts of innovation, and therefore the feebleness of the monopolistic structure. It is just through more recent empirical studies that link between the size of market and the innovation has been examined for the differentiated products.

In a set of recent economic analyzes, a forceful competition lays as a precondition in order to generate (ex-ante) favorable incentives to innovation. Therefore, a statutory relaxation through stimulating 
regulations of the competition in the products market, can facilitate the entry of firms, and in turn, reduce the administrative barriers, by eliminating the control of prices and the others operational controls. Consequently, when innovator firms get (ex-post) a certain power of market in the new products (process), the R\&D can be motivated. The capacity to discount a sufficient income, in order to cover up the costs of innovations, as well as, the existence of a potential competitor pressures in order to guarantee the continuity of innovator activities of firms constitute the good environment indispensable to their surviving. However, the importance of this environment can occur the paradox between the competition and the effectiveness of appropriability's mechanisms, especially when we are asked on the role played by spillovers of R\&D to assure the diffusion of technological change. This is why, there are not a decisive experimental results insisting on the importance of the appropriation in stimulating the innovating efforts. Indeed, an increased effectiveness of the mechanisms of protection, can lead to the emergence of a temporary monopoly rent imposing in turn a right of ownership, which can overpower not only competition to return on this crenel of market but also by dissuade any effort of R\&D in this field. Then, these mechanisms can become a dissuasive means facing the effort of innovation (Morck and Yeung, 2001). The repercussions of competition on the R\&D often appear according to the sector in question. In the sectors of weak technology, the intensity of competition stimulates the investment in the R\&D, and thus, the innovating activity with an aim of preserving the shares of market by reducing the costs and by decreasing the prices. In the technological sectors, characterized by the division of «dominant» technologies, which are relatively homogeneous, competition is accompanied by a process of "cumulative" innovation intended to reduce the costs and to improve quality compared to that of the competitors. In other sectors of high technology, competition in the markets is related to several different technologies, each one being encouraged by various innovating firms. Under this context, the efforts of R\&D are mainly intended to horizontally differentiate the products and to acquire shares on good markets, which finally have an incidence on the total productivity of the factors that it is difficult to identify. Rosenkranz (1996) considers a duopoly in a horizontally differentiated market in which the prevalent structure is that of the competition of Cournot. He shows that the firms will always invest in the innovations of products ${ }^{1}$ and processes ${ }^{2}$ and any rise in the size of market, can modify the investments in R\&D in favor the innovations of products. Bonanno and Haworth (1998) are based on a model with a vertical differentiation of product.

Only one of the two firms is likely to innovate and the firm in question must decide between the innovation of products and the innovation of processes. They discover that the firm of big (weak) size chooses the innovation of products (processes) when competition is intense (competition of Bertrand). The reversed situation is carried out when the degree of competition is weak (competition of Cournot). Filippini and Martin (2002) extend the analysis of Bonanno and Haworth (1998) in a model in which the duopolies simultaneously decide on the innovation to carry out. Their analyses lead to two balances in which the firms of large and low size choose the same type of innovation and only one asymmetrical balance. Beyond, they show that only the asymmetrical case supports a situation in which the vertical intensity of competition is relaxed. Weib (2003) analyzes the problem of the innovation like a decisional game with two stages. In the initial situation, there are two firms producing each one a variety of basic goods. Like first stage, the firms choose simultaneously one of the three following alternatives: An innovation of products, an innovation of processes or no innovation. During the second stage, the firms enter in competition in the market ${ }^{3}$. The strategic variable of the firm during the second stage of the decisional problem appears through either a variation in the price (competition of Bertrand) or a change in the quantities (competition of Cournot). A firm continuing an innovation of products, offers in the second stage related to competition, a new variety in the market and gives up the old one, which will

\footnotetext{
${ }^{1}$ The innovation of products is a change in the degree of product differentiation. According to the Schumpeterian concept, it is introduced like an investment for the creation of new goods.

${ }^{2}$ The innovation of processes is a reduction in the unit costs of production. It indicates according to the Schumpeterian approach, an investment for the production of the already existing but less expensive goods.

${ }^{3}$ In this model, the nature of products differentiation is not specified. Moreover, the nature of the market relating to the second stage is not identified, in the manner; the strategic variable of the firms can be the price like also the quantity.
} 
increase the degree of the differentiation of the products. In other words, the profits of the firm increase if the degree of competition weakens. The result of this analysis is that the small degree (high) of products differentiation (competition) slightly reinforces the introduction of new products. The firms prefer relatively the innovation of processes, if the degree of products differentiation (competition) is high (weak).

\section{Technological specialization versus technological diversification}

The notion of technological diversification was largely associated with intention expressed by firms to improve the quality of their products. According to Breschi et al. (2003), in a market of imperfect competition, and with an aim of preventing the vulnerability of the potential competitors, a firm is even more incited to improve quality of its production. This is why; the firms require "to disperse their innovating activities on several technologies". Nelson (1959) considers that the firms, which diversify their technological base, are those, which profit from new possibilities of technological innovation. Indeed, in the case in which several innovations are indicated to solve the problems that are not connected to the innovating activity of the firm, the most diversified firms will profit more from their activities of research, because they will collect more effectively the social benefits of their innovations. The empirical analysis carried out by Vega (2000) on a panel of the active European firms in R\&D, consolidates explicitly this idea. This author shows that the intensity of the R\&D and the number of the patents increase with the degree of technological diversification. The firms adopting the strategies of technological diversification can join ascending opportunities as regards the technological spillovers on the one hand, and reduction of the risks associated with the technological investments in the another share. In this last case, the keen competition (particularly in the markets with strong innovations), the technological change and the imitation are sources of economic depreciation or obsolescence of technology 4 . In this situation, the technologically diversified firms are held to invest indistinctly in R\&D, because of the diversification of their wallets of research tends to reduce the inherent risks of the R\&D projects. When the firm diversifies its efforts of $R \& D$ on several technological alternatives, it can reduce the dissension associated between the outputs and its investments in $R \& \mathrm{D}^{5}$ In other words, the actors that are downpour to the risk are been willing to invest a high proportion of their richness in the risky innovating projects (Nelson, 1959, Tirole, 1988, Scherer, 1999).

Lastly, technological diversification can prevent the negative effect of closing in only one particular technology, which thus, allows the evolution and the restoration of the firm. However, the debate technological specialization/diversification obviously upset the advantages before quoted and confined with the latter. While, according to Breschi et al. (2003), the firms which target their activities of R\&D for a limited number of technological fields, can benefit more massively from these activities. In this context, technological specialization can start again the economies of scale associated with the procedures of learning; facilitate the transfer of knowledge between essential technologies of the firm, and profit leading by «the comparative technological advantage "of the firm. In this circumstance, the specialization of the countries and the international technological trade are two facets of the same corner in which the international market of technological knowledge is applied and developed. More technologically specialized firms are more innovating than those more diversified are. The partisans of technological specialization often attach their arguments to the cumulative character of technological knowledge, which constitutes a joined product of the capacity of absorption. This specialization involves positive effects in terms of general efficiency of the procedure of innovation: The firms can concentrate on technological fields in which they hold a technological advance and therefore relying on the complementary external technological knowledge. By wondering about specialized or diversified nature relative to industrial agglomerations, the literature of the new geographical economy has discussed this dilemma a long time. Economic studies related to diversity and specialization does not lead to an explicit interpretation as for a dichotomic rupture between these two concepts. This problem is brought back even to the concept of diversity. Indeed, according to Martin and Ottaviano (1999), diversity is equivalent to an intra-sectoral

\footnotetext{
${ }^{4}$ Schumpeter (1942) characterizes this situation by the creative destruction.

${ }^{5}$ Scherer (1999) shows that on average, roughly, half of the technological projects undertaken by firms are successful.
} 
environment produced by the structure of market characterized by monopolistic competition. However, according to Jacob (1969) this term means the intersectorial relations, in others words, links between dedicated sectors each one aimed to produce goods or services without the existence of an effective proximity as regards use. In this last case, the structure of market of the type Dixit \& Stiglitz (1977) is mobilized. The idea defended by Jacob (1969) is because the most crucial externalities favorable to the life of the agglomerations are the result of the crossed fertilizations between various competences. In other words, Jacobs was based on either the double observation of the interactions between industries and services inside the great agglomerations on the one hand, and the theories of the technical change, which propose the strong propagation of the externalities between industries. Through this line, the growth would be more supported by technological diversity compared to technological specialization under the effect of the growing innovation appropriateness that presents by the means of exchange of different ideas and the new combinations: "As the number of the varieties and division of workers are significant, the capacity of the economy to add more types of goods and services is more large " (Jacobs 1969).

The agglomeration of the economic activities was obviously associated with the phenomena of concentration, the activities of production and the activities of innovation. The first would be more sensitive to the pecuniary externalities (that result from the commercial relations between the economic actors) while the seconds would rest rather on externalities of knowledge or direct communication between agents and relations face to face. Thus, the agglomeration results from the overlap of these various phenomena (Fujita and Thisse, 1997). In this context, the debate specialization / diversification becomes more and more complex and moves towards a new debate centered on the dynamic implication and the orientation externalities of R\&D to the centre or between the borders of industries. Diversity, that relates to the final goods (Krugman, 1991) or to the intermediate goods available (Krugman and Venables, 1995) was regarded as the product joint of the process of agglomeration. In the line of research of Krugman (1991), they are more particularly the commercial relations of offer and demand, taking the form of the pecuniary externalities, which are brought into the game to explain the industrial agglomeration. These externalities emerge through many configurations according to whether these commercial relations concern a dependent producer and consumer or several producers or not with vertical relations. The liberty of entry of new firms in an agglomeration can reinforce the positive pecuniary externalities for the firms previously localized in this agglomeration, through opportunities, which it presents as regards widening of the market via the additional demand that it gets. Moreover, this entry can lead to a fall of the production costs for the sectors located downstream, on the one hand, by an effect of competition and, on the other hand, by a minimization of the costs of transport. In the same way for the above-mentioned reasons, the wellbeing of the consumers improves. This downstream entrainment effect is simultaneously combined by an upstream effect. At this level, Krugman (1991) advances: «It is desirable to live and to produce under a concentration of the industrial productions due to the weakest price of the produced goods ". This is equivalent to an economy characterized by the presence of a diversity of the produced ${ }^{6}$ goods explained by the fact that the structure of market incorporated in the model of Krugman (1991) is that defined by Dixit and Stiglitz (1997), characterized by the monopolistic competition, which puts forward the role of the increasing returns inside the firms. This development is consolidated by the assumption of the mobility of workers.

The displacement of the workers in favor the area whose real wages are higher, generates a delocalization of the individual expenditure favorable to this area, and thus, increases the relative size of markets. The incorporation of the costs of transport pushes the firms with ascending returns to be located on the broadest market in order to exploit these returns. Each area accommodating a more significant number of the firms is that whose local production in differentiated goods is varied. Intended by the valorization of products variety, there will be an attraction of new consumers, which will amplify the former effect of demand and constitutes an additional reason for the agglomeration of the firms. Several models of geographical economy suppose that diversity relates also to the intermediate goods in the production of consumption goods (Krugman and Venables 1995, Venables 1996). According to Krugman and Venables (1995), beside sectors operating in perfect competition there are many industries connected by supply

\footnotetext{
${ }^{6}$ Each firm produces a single good, so that this one holds a capacity of monopoly.
} 
and demand's relations. These industries form only one sector in imperfect competition, in which a variety of good produced by a firm can constitute intermediate goods for all the other firms. These last, when they are concerned to the valorization of the diversity of intermediate goods offered on the market, have a constant returns compared to work and growing returns with the number of different factors. From these theoretical bases, it proves that the role of diversity to explain the geographical agglomeration rests on the manner and the width with which the firms and the individuals develop the differentiated goods. Granstrand (1998) tried to solve this dilemma by showing that a certain threshold of specialization is required in order to reach a necessary expertise along the procedure of research and thus improving "state-of- heart "of complex technologies. Therefore, firms can obtain a fertilization of various technologies, which are connected to its principal activities. Then, they can carry out profits through technologies exploited elsewhere by the other firms and which are not connected. The majority of the empirical analyses interested by the articulation between technological diversification and the innovation at the level of the firm are based on the proxies of the product diversification (Vega 2000). Such studies supported the existence of a correlation between product diversification and various measurements of the innovation which they are based on the intensity of the R\&D (Grabowski 1968 and Teece, 1980), the number of the technical workers (Gort, 1962), or numbers it patents (Scherer 1984). More recently, Veuglers (1997) examined the impact of the strategies of external source on the domestic expenditure of R\&D by relying on the products diversification as an additional explanatory variable. On the other hand, the approximation of technological diversification by product diversification remains relatively contestable, and many problems appear. Gambardella and Torrisi (1998) support the idea according to which technological diversification of a firm is extremely wider than its diversification of product.

Whereas technological diversification can be mainly justified by the challenge that a firm judges essential for its survival, via the improvement of its products or the reduction of the costs in a given market, product diversification is dependent on a whole of other reasons. In fact, product diversification is one of the most significant aspects of the behavior of firms during time. This is why, many studies tried to locate the factors that likely condition products diversification at a largely disaggregated level. There are several potential reasons for products diversification. Initially, Jovanovic (1993) relates this diversification to profit generated by a more important part of market: A firm, which holds a capacity of market in two substitutable products, can carry out higher profits than those of two monopolies in a single product. Then, among the crucial reasons for the diversification of product, which were frequently treated in the literature, is the risk associated with the volatility of profits.

Moreover, when the firms diversify their products to smooth their profits, they will have a greater capacity of anticipation of the future shocks. Beside, product diversification of firms can emerge because of the persistence of the decreasing returns of scale of the production. This situation creates incentives for firms to explore new productive opportunities and to support the expansion inside relatively differentiated and more attractive industries. Thus, firms characterized by decreasing returns of scale of their productive apparatuses are incited to diversify their productions. However, this advantage can be neglected if the fixed costs of the entry are weak and the firms take advantage of synergies between the productive units that divide common assets. Granstrand and al. (1997) stress that the powerful firms are those, which hold a broader variety of technologies to compete in a narrow row of products. The results of Gambardella and Torrisi (1998) reinforces this idea, by suggesting that this type of firms, although they are equipped with a spectrum of technological capacities which enable them to create more sophisticated and more developed products, focuses their field of activity in specific productive domains.

Intra-industrial trade and product diversification: Many famous models developed at the end of the 70 and at the beginning of the 80 insisted on the profits of trade, associated more specifically to intraindustrial trade based on the imperfect competition and the consumer's choices (Krugman, 1979, Lancaster, 1980, Falvey, 1981 and Falvey and Kierzkowski, 1987). This literature classified the international trade in two principal types according to their inter or intra-industrial qualified by "oneway "and "two-way" trade. Concerned by the first type of trade, the theory of Heckscher-Ohlin provides that countries specialized in the intensive abundant factors goods. With the opening of trade, countries will export certain goods, and will import others pertaining to different sectors, according to their 
comparative advantages. Intra-sectoral trade ${ }^{7}$ refuses this approach. Several theories explain the reason according to which international trade can generate sectoral flows of type "two-way ". An interesting part of these theories refers to the differentiation of product, the economies of scale and the imperfect competition (Kierzkowski, 1985 and Helpman \& Krugman, 1985). «Two-way «Flows connect trade partners who are specialized and competitor in the production and the export of similar but differentiated goods (Fontagné, Freudenberg and Péridy, 1998). Since three decades, several models of international trade have been elaborated, based on the basic concept related to the monopolistic competition. At this level, the synthesis worked out by Helpman and Krugman (1985) emerged as orthodox news. This synthesis considers that the products, which are horizontally differentiated, are theorekly valid to the consumers under forms of different varieties, and because of the opening to the international trade increases the size of the market, it will stimulate the appearance of new varieties of goods as well as the realization of economies of scale. On the other hand, the concept of the comparative advantage remains valid to the outdistanced countries in their factors endowments or technological expertise. The international trade in the horizontally differentiated goods implies that the countries offer to the various consumers, goods according to their tastes and preferences. At this level, positioning on the market is probably more sensitive to competition by the prices, because consumers can direct their preferences with different producers when the price or other characteristics varies (Hotelling, 1929). On the other hand, the international trade in the vertically differentiated goods implies that the trade partners are able to choose a different positioning of their goods in the spectrum of quality, and the offer to consumers is conditioned by the presence of different incomes and diversified preferences for quality.

The concept of horizontal differentiation was introduced in the models of endogenous growth according to the principle of the preference for the variety. Such a representation finds its origin in studies of Spence (1976), Dixit and Stiglitz (1977) and Ethier (1982). The standard model of this interpretation is that of Romer (1990) which advances that horizontal differentiation «is characterized by the preference of individuals to a widening of the variety of the available goods ". Thus, products differentiation can take the vertical or horizontal form where each product can exist in the form of several alternatives of quality or in a number of alternatives having same quality. According to Lancaster (1979), the products having the same whole of characteristics, form a sector. If it has a different proportion of characteristics, and none of them is intensively marked by a given characteristic, they are horizontally differentiated or similar. This last typology (horizontally differentiated goods), reflects the existence of different varieties at a given level of quality and reveals the preference for diversity. The understanding of the concept of horizontal differentiation was often based on an argument oriented either to demand and offer corner. Aside of demand, tastes and individual preferences expressed by the consumers for a given variety of product, implies that the aggregate demand for this variety must be the subject of a horizontal differentiation and the decision of purchase of a good must depend on the inclusion of a specific characteristics which are preferred by the consumers in spite of the prices (Chiarlone, 2000). Aside of offer, specializations of firms are due to the internal returns of scale in the production. In contrast, if a product is more strongly (slightly) marked by each characteristic than other products, it is more qualitatively higher (inferior). It is the case of vertical differentiation in which, the goods seem presented accentuated differences in their prices in contrast with horizontally differentiated goods. In such a situation, this type of differentiation results from a preference of the individuals to the qualitative improvement of goods in a fixed range. Wondering about the determinants of intra-industrial trade, Chiarlone (2000) shows that the persistence of this type of trade between the most developed countries reflects that the level of economic development as well as the size of a country plays a paramount role in the determination of the nature of international trade. At this level, the tendency, which clearly marked the European Union countries towards the intra-industrial trade and more particularly in the vertically differentiated products, is a phenomenon, which can be largely explained by the completion of the single European market ${ }^{9}$.

\footnotetext{
${ }^{7}$ M. Freudenberg and F. Lemoine (1999) identified the intra-industrial trade like the simultaneous exports and imports inside the same industry.
}

${ }^{8}$ S. Chiarlone (2000): «Importation demand with product differentiation disaggregated estimate of Italian sectoral imports ". Waring Paper n¹13, July 2000.

${ }^{9}$ Associated with dimensions of other characteristics of the European economy such as growth and convergence 
In an analysis concerned by the transition economies of eastern and central Europe, Funkle and Ruhdwel (2003) shows that the variety of products is particularly significant for the economies producing only one limited row of goods. Since the end of the 80 , the mode of the international trade of these countries was radically changed both qualitatively and quantitatively. The tariffs were reduced, many quantitative restrictions (quotas) were dismantled and controls of the exchange were virtually eliminated. Beyond, the trade was reorientated from the East to West. These developments have offered opportunities particularly targeted to the small producers who move from restricted local markets to the wide foreign markets, and thus, allowing a readjustment of their structures of production and a massive increase in their imports. For the countries having a large size markets, they offer at once, a vaster variety of products (horizontal differentiation) and a more significant spectrum of quality (vertical differentiation). In fact, the size of market tends to reinforce the share of intra-industrial trade in the total of the trade in contrast with interindustrial trade. Regarding to the effect of the returns of scale, the most developed countries are more efficient in the industries characterized by significant external economies of scale. Moreover, differences in size between the trade partners will have to promote interindustrial specialization and thus, restrict the share of intra-industrial trade. At the beginning of the 80, several models of intra-industrial trade, based on a structure of market characterized by the monopolistic competition (Dixit and Norman 1980, Krugman 1980, 1981 and Lancaster 1980) allotted a crucial role to the economies of scale for horizontal differentiation. Whereas, Dixit and Norman (1980) and Krugman $(1980,1981)$ suppose the prevalence of «love of variety" approach, Lancaster (1980) followed by Helpman (1981) insist alternatively on the importance of the «ideal variety "approach. Moreover, Eaton and Kierzkowski (1984), introduce horizontal differentiation into the context of oligopoly: If there are two identical economies and two groups of consumers having different preferences for varieties, international trade led to a situation in which, there exists in each products market only one for each variety, that in turn generates intra-industrial trade. In other words, and compared to the traditional theory of trade which suppose that the structure of specialization between industries and sectors is determined by the comparative advantages, in the recent theory of trade, specialization inside industries is principally supported by economies of scale .

The existence of the economies of scale implies that each firm inside a given industry specializes in a variety, which is not produced elsewhere as long as there exist some demand for this product in various countries. However, the number of the varieties, which is exported by a country, depends on the structure of specialization at an aggregated level, which is determined by the comparative advantages. For this reason, it is possible to observe a more intensified degree of intra-industrial trade in the total trade when the relative endowments of factors between two trade partners become more similar. Moreover, Berganstrand (1990) has recently developed a theoretical study, which explains the relationship between the share of intra-industrial trade in the total of international trade and the endowments of factors as well as the income. The basic determinants of this share that were stated by the analysis of Breganstrand (1990) are the differences in income (total and per capita), the average income and the differences in the ratios of capital/travail endowments. The determinants of intra-industrial trade specific to an industry are less explicit than those specific to the countries. However, the products are not only horizontally differentiated, but can be also qualitatively differentiated: It is the case of vertical differentiation (Falvey 1981). Such distinction modifies theoretical developments (Freudenberg and Lemoine, 1999): Following the approach of «integrated balance ", economic distance between countries is not the only base for interindustrial specialization, but can also consolidate specialization along the rows of quality inside industries. The model developed by Falvey (1981) and completed by Falvey and Kierzkowski (1987) constitutes mainly the principal reference of vertical differentiation. In the context of the theory of Heckscher-Ohlin-Samuelson, with the liberty of movement of capital between firms belonging to a given sector and either between the sectors, Falvey (1981) attaches quality of products to the capital intensity in the production. If ratio of capital / work differs inside the groups of products, the abundant countries in capital will produce and export capital-intensive products, with high quality, whereas the abundant countries in factor work export work intensive products with low quality. As an attempt to improve this reasoning, Falvey and Kierzkowski (1987) show that the consumers holding highest incomes will receive a set of varieties with highest quality and the share of vertical intra-industrial trade in the bilateral trade is all the more raise if differences in the ratios capital / work and thereafter in the incomes per capita of the two countries, are more significant. Vertical differentiation was beforehand built-in in the models of intra-industrial trade by Shaked and Sutton (1986), characterized by oligopolistic market structure. They suppose that quality of products depends on the expenditure of R\&D encrusted in the fixed costs, and so it 
is often specific to the technological sectors. By preserving the theoretical developments of Falvey (1981) and Falvey and Kierzkowski (1987), according to which consumers having more raised incomes will require goods of higher quality, balance is realized by following a game with three stages. With the opening to the international trade, and under the effect of the economies of scale, the average cost of firms, which maintain their competitiveness, decrease, and thus, enhance the profitability of R\&D.

Indeed, the commercial policy allows the transmission of the price's signals from the world market to the national economy. These signals imply the coherence and the allowance between the resources and the comparative advantages. Moreover, the localizations of firms in the various markets are posed like a stimulant of the intra-industrial trade of vertical nature. In this model, if the average costs increase in a moderate manner with the improvement of quality, the structure of market in question is that of natural oligopoly. However, the interindustrial differences in the possibilities and the extent of the decreasing costs are not necessarily articulated in a foreseeable or coherent way with the implications as regards the intra-industrial exchanges. This is strongly dependent on the nature of the products, the size of the total market and the scale of production with minimal efficiency (Greenaway and Milner 1986 p.122). In this last case, model of CHOS marks obviously that intra-industrial specialization is caused by the economies of scale, but the model postulates that the minimum scale of efficiency must be relatively weak to allow the existence of a high number of firms inside an industry. In contrast, a minimum scale of larger efficiency implies, for a given size of market a lower number of firms, and a more reduced share of intraindustrial trade in the total of the trade. Ethier (1982), shows a similar conclusion specific to the trade in the intermediate goods: "In spite of the existence of internal economies of scale and differentiation of products, the degree of such phenomena is not equivalent to an essential determinant of the extent of the intra-industrial trade ". In a model with preference in Lancaster, Greenaway and Milner (1986 chapitre4 p.112) postulated that in case of multi-product firms ${ }^{10}$, intra-industrial trade is in general more justified by the effects of economies of scale compared with the extend of decreasing costs, in order to support the presence of a significant number of firms and/or products. In fact, the presence of the significant fixed costs can not only create entry appropriateness of a new advantageous variety in the form of the entry of new firms, but also encourage multi-product firms to distribute the standing fixed overheads between a higher numbers of varieties. However, " if domestic capacity of market of the firms increases and the possibility as well as the incentive of the adoption of entry dissuasive strategies ${ }^{11}$ are reinforced more and more, the effect on the foreign entry, and thus, on the extent of intra-industrial trade becomes less foreseeable". In other words, it is not possible to affirm the existence of a continuous and direct relation between the intra-industrial trade and the extent of the economies of scale. Besides, above-mentioned determinants, Chiarlone (2000) shows that the costs of transport have negative effects on the two types of intra-industrial trade: The changes in the costs of transport and the costs of transaction in general, can affect the structure of intra-industrial trade. This negative relation between the distance (cost of transport) and the share of intra-industrial trade in the total trade is revealed through the amplified differences between the geographically outdistanced countries, in measurement that when products are substitutes (differentiated), demand is more sensitive to the differences of prices.

\section{Operational proxies of products variety}

Although theoretical studies support clearly the possibility of anecdotes results and their coherence with the stylized facts, no formal test is completed for the ultimate confirmation in favor of a given measurement of products variety ${ }^{12}$. This is probably due to the difficulty to provide direct measurements of products variety on the one hand, and to ensure the international comparability on another hand. This difficulty, which was largely at the origin of the divergence between economic theory, empirical and econometric results, is explained by the unavailability of the data relating to products variety during time and between countries. For this reason, our primary stage consists in building a database of products variety. We try in what follows to answer the two following questions:

- Which methodology we can adopt to estimate products variety between countries?

\footnotetext{
${ }^{10}$ Firms producing a number of varieties of given goods.

${ }^{11}$ These strategies are often expressed by variations in prices and range of the products.

${ }^{12}$ Even in the famous databases.
} 
- Which are the data relating to the differentiated products, largely disaggregated and coherent with our analysis inter country? In what follows, we will adopt method previously elaborated by Feenstra (1994) and Feenstra and Markusen (1994). These studies proceeded by relying on a function of production of the type CES in which the inputs are non-symmetric, in order to obtain a direct proxy of products variety. Therefore, we lay out on two units of observation related to two countries, noted $\mathrm{S}$ and $\mathrm{T}$. We suppose that the output, $\mathrm{y}$ T of the country $\mathrm{T}$ is given by the following function of production:

$$
Y_{t}=f\left(x_{t ; t} I\right)=\left[\sum_{i \in I t} a x_{i} x_{i t}^{\sigma-1 / \sigma}\right]^{\sigma / \sigma-1}
$$

Where $\sigma>1$, is the elasticity of substitution, $\mathrm{X}$ it quantity of input I in the country $\mathrm{T}$, and I T, the whole of the inputs in the country $\mathrm{T}$. If inputs available in the country $\mathrm{T}$ are counted by 1 to NR $\mathrm{T}$, we have: I T = $\{1, \ldots . . . \mathrm{NR} T\}$. The corresponding cost function is:

$$
C\left(p_{t, t}\right)_{t}=\left[\Sigma_{i \in I t} b_{i} p_{i t}^{(1-\sigma)}\right]^{1 / 1-\sigma}
$$

Where $p$ it is the price of the input and $b_{i}=a_{i}^{\sigma}$. Following Feenstra and al. (1992) and Feenstra (1994), we choose the common intermediate goods related to countries as follows ${ }^{13}$ :

$$
\mathbf{I}=\mathbf{I}_{\mathbf{s}} \cap \mathbf{I}_{\mathbf{t}}
$$

Thus, corresponding products variety PV St is formulated as follows :

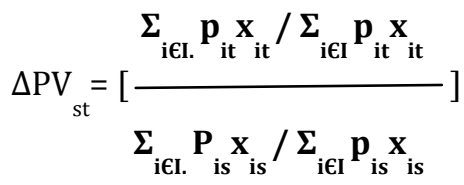

If this ratio exceeds the unit, this indicates a higher variety of products in country T than that in country S. In the particular case, where all inputs enter symmetrically, the numerator of the equation (3) is simplified to $\log \left(\mathrm{N}_{\mathrm{t}} / \mathrm{N}_{\mathrm{s}}\right)$. If this ratio is positive, it implies that country $\mathrm{T}$ disperses more slightly its outputs between the categories of products than the country S. However, the measurement of products variety based on this methodology is not safe from certain failures. Indeed, according to this approach, a very diversifying exporter must be a very diversifying producer, and reversed situation is not necessarily true. Some intermediate goods produced inside the nation are not marketed at international level. Nevertheless, such methodology has a great economic and social significance, particularly when the majority of goods are the object of international trade. Later, Funkle and Ruhwedel (2003), adopted a measure of products variety not less operational, which was founded before by Romer (1994) by creating an interaction between intensive and extensive margin of importation ${ }^{14}$. According to this methodology, as a country concentrates all its imports in a restricted number of products varieties, it will have a higher intensive margin of importation and a weaker extensive margin. In contrast, when a country distributes slightly its imports on several products varieties, it will carry out a weaker intensive margin of the imports and a higher extensive margin.

The same branch of literature (Funkle and Ruhwedel 2003), resorted to an additional measurement founded on data related to exports of a country compared to those of the United States. In order to detect the differentiated importance of each modeling approach, these economists selected the variety of exports in the category of investment goods and consumption goods. However, the indicators of products variety, which are focused only on the data of export, are criticizable. Indeed, although they are largely differentiated, inputs, which are not produced inside a country, can be massively available elsewhere. In other words, the products variety in a given country depends not only on exports but also and potentially on imports. Quality and products variety proxies are often retained from data related to the international

\footnotetext{
${ }^{13}$ Sée supposition (1) in Feenstra (1994).

14 The intensive margin of the importation measures the share of the imports of a country in the total of the world imports for the varieties of products specific to this country. The extensive margin measures the fraction of the world imports of the varieties of products specific to a country in the total of the world imports.
} 
trade. However, the explicit sensitivity of proxies based on international trade to the degree of the commercial opening of a country, tariff and nontariff barriers and with the movements of exchange rate is a major disadvantage. In the most case, theoretical method adopted in order to measure the intraindustrial trade is overlap method initiated by Grubel and Lloyd (1975) and having the following form:

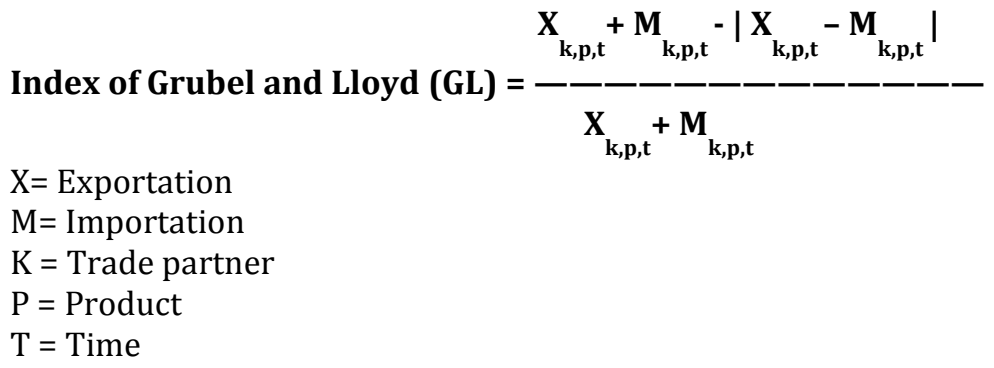

However, this method has been the object of various refinements along the empirical literature. According to Fontagné and Freudenberg (1997), the method of Grubel and Lloyd prove non relevant in measurement that it implies that majority of flows between imports and exports, consist with a trade having at once intra and interindustrial nature, whereas the minority take the form of an intra-industrial trade type. Moreover, a considerable share of intra-industrial trade can be due to an insufficient disintegration that it is geographical or sectoral. An ascending number of empirical studies distribute flows of intra-industrial trade to horizontal and vertical shares. Abd-El-Rahman (1991) uses a technique, which was since, very current, and aims to separate the two shares of intra-industrial trade by relying on the ratio of unit values / ton of exports and imports. If the ratio is outside a row that is specified beforehand, the flow of trade is defined as qualitatively differentiated. The aggregation problem arises according to two dimensions, geographical and industrial. Geographical dimension deeply insists on the failure of the multilateral approach, in measurement that according to this approach evaluation of intraindustrial trade can be largely biased: Exports of a homogeneous product towards a trade partner can be simultaneously imported of another trade partner. In the case of the incorporation of the costs of transport, this structure of trade is compatible with the traditional models of trade (Bergantrand, 1983). In order to minimize geographical aggregation bias, flows of bilateral trade are per assumption preferred to the flows of multilateral trade. The industrial dimension of aggregation problem insists on the need to apply the data related to the intra-industrial trade to a rather weak aggregation level. Fingers (1975) shows that the statistical classification of international trade data adapts with different intensities of factors for the various products. Therefore, intra-industrial trade is simply assimilated to a statistical phenomenon, characterized by an inconvenient categorization of products. In contrast, orientation of studies to weak aggregation level reinforces the existence of intra-industrial trade, which contradicts the statistical aspect of this type of trade.

Beside, problem leaded by aggregation of final goods according to their intensities of factors, these aggregation bias can be revealed through the fragmentation of production processes: On the basis of the idea according to which the activity of industries are targeted at once to final and intermediate goods, intra-industrial trade led to a raised level of aggregation, which can take the form of an exchange between the two types of final and intermediate goods. In other words, it is necessary to refer to a level of aggregation relatively weak in order to draw aside flows of trade explained by the comparative advantages. This idea is supported by Vona (1990) which shows, that as level of aggregation weakens, variation in the contents of factors decreases. In a macroeconomic scale, empirical studies have used several indexes to measure the differentiation of the international trade ${ }^{15}$. A significant number of this studies resorted to the methodology developed by Abd-El-Rahman (1986) and Freudenberg and Muller (1992). This methodology is based on the «overlap» index and is formulated as follows:

\footnotetext{
${ }^{15}$ Few attempts relating to the products diversification were led at the microeconomic scale. Among these analyses, we can quote those of Gollop and Monahan (1991), which show that until 1982, firms are specialized inside the factories but are diversified between the factories. More recently, NR Kim (2002) used the index of Herifindhal to measure diversification at the level of the establishment and the firm.
} 


$$
\text { Index of Overlap (IO) }=\frac{\operatorname{Min}\left(\mathrm{X}_{\mathrm{k}, \mathrm{p}, \mathrm{t}}, \mathrm{M}_{\mathrm{k}, \mathrm{p}, \mathrm{t}}\right)}{\operatorname{Max}\left(\mathrm{X}_{\mathrm{k}, \mathrm{p}, \mathrm{t}} \mathrm{M}_{\mathrm{k}, \mathrm{p}, \mathrm{t}}\right)}
$$

The overlap index can reconcile between the two incompatible paradigms related to the two types of international trade, based on the imperfect competition on one side, and the perfect competition of another side. This last indicator measures the extent of overlapping between imports (M) and exports (X) of a two countries in their structures of international trade. If it is high, this is equivalent to a significant overlapping. In this last case, we consider overlap as a structural specificity of international trade and flow is assimilated to «two-way "trade. In the contrary case, overlap cannot be described as structural. It is the case of "one-way " trade. Thus the existence of " two-way "flow, is revealing of a product differentiation (horizontal and vertical). Consequently, it is possible to operate a rupture of bilateral trade between that in the homogeneous products and that in the differentiated products. Generally, if the index of overlap exceeds a certain arbitrarily fixed threshold, the total trade of this product is assimilated to a «two-way "flow. A change of this threshold, implies a modification of the extent of inter and intraindustrial specialization. A weaker threshold value reduces the importance of interindustrial specialization. At this stage, we follow Freudenberg et al. (1998) and we select a threshold of $10 \%$ in order to distinguish between «one-way" and " two-way "flows. If overlap is higher than $10 \%$, flows are characterized by differentiated products, if not, they are homogeneous. With regard to typologies of differentiation and by reasoning at a sufficiently disaggregated sectoral level, the qualitatively differentiated goods will have to reveal increased differences in the prices, contrary to other goods. Compared to our level of disaggregation, the indices of unit value represent a reliable " proxies " of the prices of goods, and thus, we can resort to the index of quality to measure the differences in qualities between imported and domestic goods. In other words, the distinction between the two types of differentiation, horizontal and vertical, refers to the criterion of similarity of products, based in its turn on the ratio between the unit value of exports (UV(X)) and imports (UV (M)). This criterion can analytically be formulated as follow:

$$
\text { Index of quality }=\frac{\mathrm{UV}(\mathrm{X})}{-\overline{U V(M)}}
$$

If the index of quality is very high or very weak, the differences in prices indicate differences in quality between imported and domestic goods. If it is close to the unit, this is equivalent to a qualitative similarity. To be done, we have followed the literature (Freudenberg and Lemoine1999) and we resorted to an exogenic interval of values $\left.{ }^{16}\right] 1 / 1+\alpha, 1+\alpha[(16)$. If quality index is external to this interval, the flows of trade refer to the qualitatively differentiated goods, if not, it concern the horizontally differentiated goods. With regard to the vertical differentiation, two types of case arise: It is considered superior if quality index is included in the interval] $1+\alpha,+\infty$ [, and inferior if this index belongs to the interval [0, $1 / 1+\alpha]$. Chiarlone (2000) attribute to country adopting the superior vertical differentiation the opportunity of an exporter of quality, and an importer of quality for that according a strategy of inferior vertical differentiation. The parameter $\alpha$ is a factor of dispersion arbitrarily fixed. In general, $\alpha$ is fixed to 0,15 . This value shows that in the case of intra-industrial trade, the costs of transport are improbably incorporated in the prices of products, in order to measure the difference between the unit values of exports and imports with a variation limited to $\pm 15^{17}$. If the index of quality reveals that the quality of exports is higher than of imports, this reflects a better positioning on the world's market compared to the trade partners and national industries are protected by competition of the prices. In the contrary case, a qualitatively underprivileged positioning implies that national exports can be unfavorably affected by competition following the emergence of producers adopting a weak price and low quality. The basic

\footnotetext{
16 This interval appears much more rigorous than that traditionally used in the economic literature of value ] $1 \alpha, 1+\alpha[$.

${ }^{17}$ In several similar studies, the value of 0,15 were considered very weak. Difference between CIF (for the imports) and FOB (for exports) with itself, considered only at $10 \%$ on average.
} 
assumption of criterion previously mentioned is that prices (unit values) are assimilated to reliable indicators of qualities. This positive relation between price and quality reflects that in the context of perfect information, a given variety of a good can be sold at a higher price if it has a higher quality. In spite of criticisms addressed to the proxies based on the unit value (in the short term, the consumers can buy a more expensive product for reasons other than quality), this approach was usually used by an alluring line of empirical studies (Gullstrand 2001). This branch of literature, supposes that at least, at a sufficiently disaggregated level, the relative prices can reflect relative qualities. The application of the two above-mentioned indices, overlap index and quality index, allows the classification of each flow of trade, and thereafter, the degree and the nature of the product differentiation at a high level of disaggregation to avoid any bias of aggregation that it is geographical or industrial.

\section{Results}

Case of Tunisia: The procedure above, relative to proxies of the products differentiation, is applied in the case of Tunisia by relying on the data based on international standard by industry classification (ISIC, revision 3). In fact, this database presents some limits: According to this methodology, a much-diversified exporter must be necessarily a much-diversified producer and the reversing case is not always true. Nevertheless, since the countries of our sample pursued a policy of trade liberalization of great scale, such insufficiencies can be neglected. Moreover, such methodology can overtake the geographical or industrial aggregation problems. Therefore, we opted to direct our analysis towards the differentiation structure of Tunisian products with the 13 OECD countries (see appendix A). Beyond, in order to apprehend clearly the sectoral share of the differentiation structure of Tunisian products, we targeted our analysis to the 8 following manufacturing sectors: Agriculture, hunting and forestry (AHF); food, beverage and tobacco (FBT); mining, quarrying and petroleum (MQP); chemicals (CP); wood, paper and printing (WPP); textile, leathers and footwear (TLF); basic metals and fabricated metal products (BMMP); electrical machinery (EM). Former empirical analyses classified the European Union Countries in two principal groups, which correspond to the "cores " and " peripherals " countries. Generally the first group is composed of countries in which intra-industrial trade represents a value superior to the half of total intra-European trade. This structure of trade is explained by fast convergence of the most developed European countries. The second group corresponds to the countries whose levels of economic development are lower and they are characterized by an interindustrial specialization. From table $n^{\circ} 1$ trade in the vertically differentiated products covers a more significant number of sectors and trade partners that in the horizontally differentiated products during the period 2004-2007. This indicates a specialization in the rows of the quality inside the sectors and which takes place on a largely disaggregated level. The intraindustrial trade in the horizontally differentiated products, relates to primarily France, Spain, United Kingdom, and on a less level, Italy, Belgium and Denmark. This type of differentiation is practically null with certain trade partners with knowing Finland and United States during the period 2004-2007.The prevalence of vertical flows on horizontal flows translates a position of fight against the potential competing pressures launched elsewhere. At the sectoral level, the stylized facts exposed in table $\mathrm{n}^{\circ} 2$, reflect the importance of the structure of vertical differentiation compared to that horizontal during the period 2002-2007. The index of quality often reveals negligible shares to see null commercial flows in the horizontally differentiated products in particular in the sectors of food, beverages and tobacco wood, paper and printing; agriculture, hunting and forestry; mining, quarrying and petroleum and basic metals and fabricated metal products. 
Table 1: Index of quality of Tunisia by country and sector during the period 2004-2007.

\begin{tabular}{|c|c|c|c|c|c|c|c|c|c|}
\hline Country & Year & AHF & WPP & FBT & $\mathbf{C P}$ & MQP & BMMP & TLF & EM \\
\hline \multirow{3}{*}{ Germany } & 2004 & $0,309^{*}$ & $5,932 * * *$ & & $0,444^{*}$ & $0,875^{* *}$ & $0,347^{*}$ & $0,592^{*}$ & $0,759^{*}$ \\
\hline & 2005 & $5,422^{* * *}$ & $1,348^{* * *}$ & & & $0,341^{*}$ & $0,283^{*}$ & $0,797^{*}$ & $0,718^{*}$ \\
\hline & 2006 & $10,775^{* * * *}$ & $1,396^{* * *}$ & & $1,182^{* * *}$ & $0,131^{*}$ & $0,759^{*}$ & $0,634^{*}$ & $0,741^{*}$ \\
\hline \multirow{6}{*}{ Belgium } & 2007 & $3,795^{* * *}$ & $1,250^{* * *}$ & & & $0,120^{*}$ & $0,070^{*}$ & $0,473^{*}$ & $0,783^{*}$ \\
\hline & 2004 & $0,322^{*}$ & $9,641^{* * *}$ & $1,463^{* * *}$ & $0,710^{*}$ & $2,579 * * *$ & $11,141^{* * *}$ & $1,331^{* * *}$ & $2,261^{* * *}$ \\
\hline & 2005 & $0,688^{*}$ & $1,608^{* * *}$ & $0,871^{* *}$ & $24,441^{* * *}$ & $2,377^{* * *}$ & $0,499^{*}$ & $1,410^{* * *}$ & $1,690^{* * *}$ \\
\hline & 2006 & $0,011^{*}$ & $1,044^{* *}$ & $0,450^{*}$ & $0,106^{*}$ & $1,572^{* * *}$ & $13,951^{* * *}$ & $1,510^{* * *}$ & $71,111^{* * *}$ \\
\hline & 2007 & $0,046^{*}$ & $4,346^{* * *}$ & $0,487^{*}$ & $1,554^{* * *}$ & & $1,274^{* * *}$ & $1,103^{* *}$ & $1,744^{* * *}$ \\
\hline & 2004 & $0,917^{* *}$ & & $0,277^{*}$ & & & $0,669^{*}$ & & $1,143^{* *}$ \\
\hline \multirow{3}{*}{$\begin{array}{l}\text { Danmark } \\
\text { Danemark }\end{array}$} & 2005 & $0,967^{* *}$ & $0,654^{*}$ & & & $0,317^{*}$ & & $0,287^{*}$ & $0,760^{*}$ \\
\hline & 2006 & $0,858^{*}$ & $0,474^{*}$ & & & $0,016^{*}$ & & $0,580^{*}$ & $1,970^{* * *}$ \\
\hline & 2007 & & $1,189^{* * *}$ & & & $0,010^{*}$ & $0,035^{*}$ & $0,207^{*}$ & $0,828^{*}$ \\
\hline \multirow{5}{*}{ Spain } & 2004 & $22,734^{* * *}$ & $2,265^{* * *}$ & $1,320^{* * *}$ & $4,935^{* * *}$ & $0,290^{*}$ & $0,205^{*}$ & $0,868^{*}$ & $1,075^{* *}$ \\
\hline & 2005 & $1,106^{* *}$ & $4,141^{* * *}$ & $0,550^{*}$ & $0,178^{*}$ & $0,125^{*}$ & $0,775^{*}$ & $1,663^{* * *}$ & $1,277^{* * *}$ \\
\hline & 2006 & $1,113^{* *}$ & & $0,429^{*}$ & $4,935^{* * *}$ & $24,988^{* * *}$ & $6,107^{* * *}$ & $0,868^{*}$ & $1,075^{* *}$ \\
\hline & 2007 & $1,443^{* * *}$ & & $0,157^{*}$ & $0,431^{*}$ & $1,993^{* * *}$ & $0,502^{*}$ & $1,392^{* * *}$ & $1,144^{* *}$ \\
\hline & 2004 & & & & & $0,001^{*}$ & & $1,192^{* * *}$ & \\
\hline \multirow{3}{*}{$\begin{array}{l}\text { Finland } \\
\text { Finlande }\end{array}$} & 2005 & & & & & $0,001^{*}$ & & $1,503^{* * *}$ & \\
\hline & 2006 & & & $0,226^{*}$ & & $1,589 * * *$ & & $0,842^{*}$ & \\
\hline & 2007 & & & & & $0,013^{*}$ & & $0,712^{*}$ & \\
\hline France & 2004 & $0,120^{*}$ & $3,900 * * *$ & $0,165^{*}$ & $1,438^{* * *}$ & $1,099^{* *}$ & $0,787^{*}$ & $1,412^{* * *}$ & $1,405^{* * *}$ \\
\hline \multirow{3}{*}{ France } & 2005 & $3,272^{* * *}$ & $2,666^{* * *}$ & $1,174^{* * *}$ & $1,018^{* *}$ & $2,843^{* * *}$ & $3,122^{* * *}$ & $1,072^{* *}$ & $1,149^{* *}$ \\
\hline & 2006 & $1,197^{* * *}$ & $2,668^{* * *}$ & $1,261^{* * *}$ & $6,184^{* * *}$ & $3,952^{* * *}$ & $0,725^{*}$ & $1,479^{* * *}$ & $1,030^{* *}$ \\
\hline & 2007 & $0,434^{*}$ & $1,878^{* * *}$ & $1,566^{* * *}$ & $1,124^{* *}$ & $2,859 * * *$ & $2,538^{* * *}$ & $1,012^{* *}$ & $0,996^{* *}$ \\
\hline Italy & 2004 & & & & $2,717^{* * *}$ & $1,539 * * *$ & $2,881^{* * *}$ & $1,263^{* * *}$ & $1,610^{* * *}$ \\
\hline \multirow{3}{*}{ Italie } & 2005 & & & & $2,011^{* * *}$ & $21,923^{* * *}$ & $0,997^{* *}$ & $0,985^{* *}$ & $1,388^{* * *}$ \\
\hline & 2006 & $0,276^{*}$ & $1,553^{* * *}$ & & $1,395^{* * *}$ & $10,548^{* * *}$ & $0,800^{*}$ & $1,851^{* * *}$ & $1,200^{* * *}$ \\
\hline & 2007 & $21,968 * * *$ & $3,462^{* * *}$ & & $2,364^{* * *}$ & $11,559^{* * *}$ & $1,156^{* * *}$ & $0,453^{*}$ & $1,294^{* *}$ \\
\hline Netherland & 2004 & $0,002^{*}$ & & & $0,149^{*}$ & $1,849^{* * *}$ & & $0,760^{*}$ & $2,756^{* * *}$ \\
\hline \multirow{4}{*}{ Pays bas } & 2005 & $0,918^{* *}$ & $2,391^{* * *}$ & & $0,139^{*}$ & $2,756^{* * *}$ & & $0,569^{*}$ & $1,700^{* * *}$ \\
\hline & 2006 & $0,004^{*}$ & & $1,372^{* * *}$ & $0,157^{*}$ & $2,490^{* * *}$ & $0,423^{*}$ & $0,628^{*}$ & $2,029 * * *$ \\
\hline & 2007 & $0,293^{*}$ & & & $14,839^{* * *}$ & $2,597 * * *$ & $1,192^{* * *}$ & $0,891^{* *}$ & $1,181^{* * *}$ \\
\hline & 2004 & & $0,967 * *$ & $0,655^{*}$ & $0,757^{*}$ & $0,007^{*}$ & $0,598^{*}$ & $0,585^{*}$ & \\
\hline \multirow{4}{*}{$\begin{array}{l}\text { United } \\
\text { Kingdom }\end{array}$} & 2005 & $0,051^{*}$ & $0,829^{*}$ & $0,462^{*}$ & $0,568^{*}$ & $1,203^{* * *}$ & & $0,775^{*}$ & $0,777^{*}$ \\
\hline & 2006 & $0,227^{*}$ & $6,273^{* * *}$ & $0,197^{*}$ & $0,844^{*}$ & & & $0,902^{* *}$ & $0,919^{* *}$ \\
\hline & 2007 & $0,004^{*}$ & $1,389 * * *$ & $0,455^{*}$ & $0,638^{*}$ & & $3,789 * * *$ & $0,973^{* *}$ & $0,781^{*}$ \\
\hline & 2004 & & & $0,218^{*}$ & & & $0,218^{*}$ & $0,370^{*}$ & $0,110^{*}$ \\
\hline \multirow[t]{4}{*}{ Sweden } & 2005 & & & $0,443^{*}$ & & & & $0,391^{*}$ & $0,139^{*}$ \\
\hline & 2006 & $0,218^{*}$ & & & & $0,020^{*}$ & & $0,423^{*}$ & $0,110^{*}$ \\
\hline & 2007 & & & $0,618^{*}$ & & $0,996^{* *}$ & & $0,422^{*}$ & $0,227^{*}$ \\
\hline & 2004 & $0,036^{*}$ & & & & $0,104^{* *}$ & & $0,557^{*}$ & \\
\hline \multirow{4}{*}{ Canada } & 2005 & $0,450^{*}$ & & & & $0,433^{*}$ & & $0,372^{*}$ & \\
\hline & 2006 & & & & & $0,067^{*}$ & $2,097 * * *$ & $0,596^{*}$ & \\
\hline & 2007 & & $4,240^{* * *}$ & & & & $0,057^{*}$ & $1,470^{* * *}$ & \\
\hline & 2004 & & & $0,519^{*}$ & $0,065^{*}$ & & $0,263^{*}$ & $0,50245^{*}$ & \\
\hline \multirow{3}{*}{$\begin{array}{l}\text { United } \\
\text { States } \\
\text { Etats-Unis }\end{array}$} & 2005 & & & $0,225^{*}$ & & $0,192^{*}$ & & $0,312^{*}$ & \\
\hline & 2006 & $0,166^{*}$ & & $0,087^{*}$ & $0,041^{*}$ & & $4,443^{*}$ & $0,711^{*}$ & \\
\hline & 2007 & & $0,358^{*}$ & $0,784^{*}$ & & & $6,547^{* * *}$ & $0,279^{*}$ & \\
\hline \multirow{4}{*}{ Japan } & 2004 & & $0,422^{*}$ & & & & & $0,756^{*}$ & \\
\hline & 2005 & & $0,329^{*}$ & & & $0,034^{*}$ & & $0,360^{*}$ & \\
\hline & 2006 & & $0,942^{* *}$ & & & $0,012^{*}$ & & $0,285^{*}$ & \\
\hline & 2007 & & $0,323^{*}$ & & & $0,018^{*}$ & & $0,558^{*}$ & \\
\hline
\end{tabular}

Source: Our calculation and database of National Institute of statistics

${ }^{*}$ ) The index of quality is included in the interval [0, 0,87 [ what indicates a vertical and inferior differentiation..$^{(*)}$ The index of quality belongs to the interval $[0,87,1,15]$ what indicates a horizontal differentiation. ${ }^{(* *)}$ The index of quality is included in the interval ] 1,15, $+\infty$ [ what indicates a vertical 
and superior differentiation. The empty boxes show that the international trade of Tunisia is of the interindustrial type.

This situation is explained by the fact that Tunisia holds a comparative advantage in the sectors of agriculture, hunting and forestry and agro food, beverages and tobacco: the comparative advantage in these sectors explains commercial flows at a rate of 52\% in 2003 and 56\% in 2007 respectively (see table $\mathrm{n}^{\circ} 2$ ). For the sectors of agriculture, hunting and forestry; food, beverages and tobacco and basic metals and fabricated metal products, one notes starting from table $\mathrm{n}^{\circ} 1$, a more considerable share of commercial flows in the vertically and inferior differentiated products that in the vertically and superior differentiated products. In other words, Tunisia is a mainly importer of quality in the above mentioned sectors. This structure of products differentiation reflects an underprivileged position of Tunisian industries belonging to such sectors and also translated the intensity of the competition, which it faces. Indeed, the Tunisian products can unfavorably be affected by the new competitors of the emerging countries, which are able to produce the same goods with weaker prices. The competitive position of Tunisia improved in the sectors agriculture, hunting and forestry and basic metals and fabricated metal products in 2005 and 2007. The observation of the sectoral structure of vertical differentiation through the index of quality, also shows that Tunisia specializes favorably in the spectrum of quality relating to the sectors of mining, quarrying and petroleum and wood, papers and printing. Indeed, the sector of mining, quarrying and petroleum recorded ascending and significant commercial flows shares in the qualitatively and superior differentiated products passing from $42.1 \%$ to $96.6 \%$ of the total of commercial flows in the differentiated products during the period 2002-2007. The same competitive position characterizes the sector of wood, paper and printing which carried out massive shares of superior and vertical products being able to reach $96,5 \%$ of the total of commercial flows in the differentiated products in 2006. This can be explained by the importance of the initial equipments that Tunisia holds in these two sectors.

\section{Conclusion}

The analysis of products differentiation derived at a sufficiently disaggregated level, and based on indicators related to the international trade, led us to emphasize the role of geographical proximity in order to explain the structure of the international trade, and in turn, the extent of products differentiation. Indeed, the one-way trade is mainly directed to countries other than those of the European Union and relatively outdistanced from Tunisia that is Canada, the United States and Japan. The recourse to the index of quality reveals that for the majority of the trade partners of Tunisia, the trade in the vertical differentiated products is much more significant than in the horizontal differentiated products during 2000-2007. In other words, the two-way trade is particularly explained by the vertical differentiation of products. The prevalence of vertical flows on horizontal flows reflects the intensity of international competition that Tunisia faces in the manufacturing sectors previously analyzed. This position is sometimes underprivileged in particular in sectors such as agriculture, hunting and forestry; food, beverage and tobacco; and basic metals and fabricated metal products. In these sectors the share of vertical and inferior differentiation interests beyond half of trade flows. In contrast, Tunisia is mainly an exporter of quality in mining, quarrying and petroleum because of vertical and superior differentiation dominates in this sector. Finally, the sectoral distribution of differentiation structure shows that the strategy of products diversification revealed through the analysis of the extend of the horizontal differentiation of products is, practically absent in the sectors such as agriculture, hunting and forestry and basic metals and fabricated metal products. In spite of the contributions resulting from this research concretized in particular by the development of a new measurement of the product differentiation applied to a sufficiently disaggregated sectoral level, several limits can be posed. Indeed, this study remains an attempt among others to measure the extent of the product differentiation. Thus, it is important even crucial the question relating to a final and unanimously attested measurement of product differentiation in order to adopt a comparative approach on an international scale. 
Table 2: Evolution of products differentiation of Tunisia (in \% of total trade flows): Per sector 2000-2007

\begin{tabular}{|c|c|c|c|c|c|c|c|c|c|c|c|c|c|c|c|c|}
\hline \multirow[b]{2}{*}{ Sectors } & \multicolumn{8}{|c|}{ Inter-industrial trade } & \multicolumn{8}{|c|}{ Intra-industrial trade } \\
\hline & 2000 & 2001 & 2002 & 2003 & 2004 & 2005 & 2006 & 2007 & 2000 & 2001 & 2002 & 2003 & 2004 & 2005 & 2006 & 2007 \\
\hline $\begin{array}{l}\text { Agriculture, } \\
\text { hunting and } \\
\text { forestry }\end{array}$ & 39.60 & 61.80 & 17.40 & 52.00 & 43.90 & 39.10 & 13.00 & 33.80 & 60.40 & 38.20 & 82.60 & 48.00 & 56.10 & 60.90 & 87.00 & 66,20 \\
\hline $\begin{array}{l}\text { Food, } \\
\text { beverages } \\
\text { and tobacco }\end{array}$ & 40.80 & 41.40 & 42.60 & 31.00 & 54.50 & 53.90 & 49.80 & 56.00 & 59.20 & 58.60 & 57.40 & 69.00 & 45.50 & 46.10 & 50.20 & 44.00 \\
\hline Chemicals & 5.00 & 7.20 & 14.60 & 2.10 & 5.10 & 15.70 & 3.20 & 15.80 & 95.00 & 92.80 & 85.40 & 97.90 & 94.90 & 84.30 & 96.80 & 84.20 \\
\hline $\begin{array}{l}\text { Textile, } \\
\text { leathers and } \\
\text { footwear }\end{array}$ & 0.60 & 0.50 & 0.30 & 0.10 & 0.06 & 0.00 & 0.00 & 0.00 & 99.40 & 99.50 & 99.70 & 99.90 & 99.94 & 100 & 100 & 100 \\
\hline $\begin{array}{l}\text { Wood, } \\
\text { paper and } \\
\text { printing }\end{array}$ & 23.10 & 36.80 & 48.90 & 19.00 & 34.80 & 44.10 & 44.50 & 39.30 & 76.90 & 63.20 & 51.10 & 81.00 & 65.20 & 55.90 & 55.50 & 60.70 \\
\hline $\begin{array}{l}\text { Mining, } \\
\text { quarrying } \\
\text { and } \\
\text { petroleum }\end{array}$ & 11.00 & 0.10 & 52.90 & 0.10 & 1.50 & 0.01 & 7.70 & 14.00 & 89.00 & 99.90 & 47.10 & 99.90 & 98.50 & 99.99 & 92.30 & 86.00 \\
\hline $\begin{array}{l}\text { and } \\
\text { fabricated } \\
\text { metal } \\
\text { products }\end{array}$ & 24.80 & 57.30 & 21.00 & 10.80 & 5.40 & 13.40 & 4.10 & 0.80 & 75.20 & 42.70 & 79.00 & 89.20 & 94.60 & 86.60 & 95.90 & 99.20 \\
\hline $\begin{array}{l}\text { Electrical } \\
\text { machinery }\end{array}$ & 3.90 & 6.40 & 2.40 & 0.20 & 9.70 & 2.60 & 2.60 & 2.90 & 96.10 & 93.60 & 97.60 & 99.80 & 90.30 & 97.40 & 97.40 & 97.10 \\
\hline
\end{tabular}

Source: Our calculation and database of National Institute of statistics.

Table $n^{\circ} 3$ : Structure of products differentiation of Tunisia (in \% of total trade flows): Per sector in 2002-2007

\begin{tabular}{|c|c|c|c|c|c|c|c|c|c|c|c|c|c|c|c|c|c|c|}
\hline \multirow{2}{*}{ Sectors } & \multicolumn{6}{|c|}{ Horizontal differentiation } & \multicolumn{6}{|c|}{ Vertical and inferior differentiation } & \multicolumn{6}{|c|}{$\begin{array}{l}\text { Vertical and superior } \\
\text { differentiation }\end{array}$} \\
\hline & 2002 & 2003 & 2004 & 2005 & 2006 & 2007 & 2002 & 2003 & 2004 & 2005 & 2006 & 2007 & 2002 & 2003 & 2004 & 2005 & 2006 & 2007 \\
\hline $\begin{array}{ll}\text { Agriculture, } & \\
\text { hunting } & \text { and } \\
\text { forestry }\end{array}$ & 3.0 & 0.0 & 0.6 & 32.9 & 17.2 & 0.0 & 86.6 & 55.2 & 79.1 & 14.5 & 43.8 & 39.8 & 10.4 & $\begin{array}{ll}44.8 \\
\end{array}$ & 20.3 & 52.6 & 39.0 & 60.2 \\
\hline $\begin{array}{l}\text { Food, beverages } \\
\text { and tobacco }\end{array}$ & 10.1 & 0.3 & 0.0 & 2.3 & 0.0 & 0.0 & 53.4 & 70.4 & 48.3 & 65.9 & 76.5 & 67.7 & 36.5 & 29.3 & 51.7 & 31.8 & 23.5 & 32.3 \\
\hline $\begin{array}{l}\text { Mining, quarrying } \\
\text { and petroleum }\end{array}$ & 2.9 & 24.1 & 19.7 & 0.0 & 0.0 & 0.1 & 55.0 & 1.8 & 19.7 & 15.3 & 0.6 & 3.3 & 42.1 & 74.1 & 60.6 & 84.7 & 99.4 & 96.6 \\
\hline Chemical & 43.1 & 45.8 & 0.0 & 61.5 & 0.0 & 45.3 & 13.5 & 27.9 & 26.5 & 28.6 & 14.2 & 14.8 & 43.4 & 26.3 & 73.5 & 9.9 & 85.8 & 39.9 \\
\hline $\begin{array}{l}\text { Wood, paper and } \\
\text { printing }\end{array}$ & 0.0 & 15.7 & 3.9 & 0.0 & 3.4 & 0.0 & 12.9 & 74.9 & 2.8 & 4.6 & 0.1 & 12.4 & 87.1 & 9.4 & 93.3 & 95.4 & 96.5 & 87.6 \\
\hline $\begin{array}{l}\text { Textile, leathers } \\
\text { and footwear }\end{array}$ & 41.1 & 3.4 & 0.0 & 65.6 & 3.2 & 47.6 & 51.1 & 57.9 & 26.6 & 21.3 & 17.4 & 48.0 & 7.8 & 38.7 & 73.4 & 13.1 & 79.4 & 4.4 \\
\hline $\begin{array}{l}\text { Basic metals and } \\
\text { fabricated metal } \\
\text { products }\end{array}$ & 32.1 & 0.0 & 0.0 & 33.2 & 0.0 & 0.0 & 67.9 & 64.5 & 62.1 & 31.4 & 64.6 & 23.0 & 0.0 & 35.5 & 37.9 & 35.4 & 16.4 & 77.0 \\
\hline $\begin{array}{l}\text { Electrical } \\
\text { machinery }\end{array}$ & 0.1 & 44.8 & 2.6 & 48.9 & 57.1 & 69.9 & 37.1 & 34.0 & 33.1 & 32.6 & 29.7 & 28.5 & 62.8 & 21.1 & 64.3 & 18.5 & 13.2 & 1.6 \\
\hline
\end{tabular}

Source: Our calculation and database of National Institute of statistics.

Moreover, the dynamics of diversification of the products revealed through the analysis of the extent of horizontal differentiation shows that commercial flows of Tunisia are more geographically dispersed in the vertically differentiated products than in the horizontally differentiated products (see Table ${ }^{\circ} 4$ ).

In other words, the products varieties in Tunisia are intended to a specific trade partners: Italy for the sectors of agriculture, hunting and forestry; mining, quarrying and petroleum and electrical machinery, France for the sectors of chemical; textile, leathers and footwear and electrical machinery, Netherlands for the sectors of chemical and textile, leathers and footwear, Sweden for the sector of mining, quarrying and petroleum, and Belgium and the United Kingdom for the sector of textile, leathers and footwear. 
Table 4: Structure of products differentiation of Tunisia (in 2007): Per country and sector

\begin{tabular}{|c|c|c|c|}
\hline Sector & Horizontal differentiation & $\begin{array}{l}\text { Vertical and inferior } \\
\text { differentiation }\end{array}$ & $\begin{array}{l}\text { Vertical and superior } \\
\text { differentiation }\end{array}$ \\
\hline $\begin{array}{l}\text { Agriculture, hunting } \\
\text { and forestry }\end{array}$ & Italy & $\begin{array}{l}\text { Belgium France Netherland } \\
\text { United Kingdom }\end{array}$ & Germany \\
\hline $\begin{array}{l}\text { Food, beverages and } \\
\text { tobacco }\end{array}$ & & $\begin{array}{l}\text { Belgium United Kingdom Sweden } \\
\text { United States }\end{array}$ & France \\
\hline Chemical & France Netherland & United Kingdom & Belgium Italy \\
\hline $\begin{array}{l}\text { Wood, paper and } \\
\text { printing }\end{array}$ & & United states Japan & $\begin{array}{l}\text { Germany Belgium Danmark } \\
\text { France Italy United } \\
\text { Kingdom Canada }\end{array}$ \\
\hline $\begin{array}{l}\text { Textile, leathers and } \\
\text { footwear }\end{array}$ & $\begin{array}{l}\text { Belgium France } \\
\text { Netherland United Kingdom }\end{array}$ & $\begin{array}{l}\text { Germany Danmark Finland } \\
\text { Italy Sweden United States } \\
\text { Japan }\end{array}$ & Canada \\
\hline $\begin{array}{l}\text { Mining, quarrying } \\
\text { and petroleum }\end{array}$ & Italy Sweden & $\begin{array}{l}\text { Germany Danemark Finland } \\
\text { Japan }\end{array}$ & France Netherland \\
\hline $\begin{array}{l}\text { Basic metal and } \\
\text { fabricated metal } \\
\text { products }\end{array}$ & & Germany Danmark Canada & $\begin{array}{l}\text { Belgium France Italy } \\
\text { Netherland United Kingdom } \\
\text { United States }\end{array}$ \\
\hline Electrical machinery & France Italy & $\begin{array}{l}\text { Germany Danmark United } \\
\text { Kingdom Sweden }\end{array}$ & Belgium Netherland \\
\hline
\end{tabular}

Source: Our calculation and database of National Institute of statistics.

\section{References}

Abd-El-Rahman, K. (1986). Réexamen de la définition et de la mesure des échanges croisés de produits similaires entre les nations. Revue Economique, 37, 307-340.

Abd-El-Rahman, K. (1991). in Freudenberg et Lemoine (1999), Central and Eastern European countries in the international division of labour in Europe », CEPII, document de travail No. 99-05, Avril.

Arrow, K. (1962). The economic implications of learning by doing. Review of Economic Studies, 29, 155173.

Bonanno, G. \& Haworth, B. (1998). Intensity of competition and the choice between product and process innovation. International Journal of Industrial Organization, 16, 459-510.

Berganstrand, J. H. (1983). Measurement and Determinants of Intra-Industry International Trade. In P.K.M. Tharakan (ed.), Intra-Industry Trade: Empirical and Methodological Aspects, Elsevier Science \& Technology Books.

Berganstrand, J. H. (1990). The Heckscher-Ohlin-Samuelson model, the linder hypothesis and the determinant of bilateral intra-industry trade. Economic Journal, 100, 1216-1229.

Breschi, S., Lissoni, F. \& Malerba, F. (2003). Knowledge-relatedness in firm technological diversification. Research Policy, 32(1), 69-87.

Chiarlone, S. (2000). Import demand with product differentiation disaggregated estimation of Italian sectoral imports, Working Papers $n^{\circ} .113$, juillet, in: http://www.Cespri.Uni-bocconi.it /

Chiarlone, S. (2000). Evidence of product differentiation and relative quality in Italian trade», Working Papers $n^{\circ} .114$, juillet, in: http://www.Cespri.Uni-bocconi.it /

Cohen, W. M. \& Klepper, S. (1996). Firm Size and the Nature of Innovation within Industries the Case of Process and Product R\&D. The Review of Economics \& Statistics, 78, 232-243.

Dixit, A. \& Norman, V. (1980). Theory of international trade: A dual general equilibrium approach, Cambridge University Press.

Dixit, A. \& Stiglitz, J. (1977). Monopolistic competition and optimum product diversity. American Economic Review, 67, 297-308.

Ethier, W. (1982). Natural and international returns to scale in modern theory of international trade. American Economic Review, 72(3), 389-405.

Eaton, J. \& Kierzkowski, H. (1984). Oligopolistic competition, product variety and international trade in $\mathrm{H}$. Kierzkowski; Monopolistic competition and international trade, New York, Oxford University Press.

Falvey, R. E. (1981). Commercial policy and intra-industry trade. Journal of International Economics, 11, 495-511.

Falvey, R. E. \& Kierzkowski, H. (1987). Product quality, intra-industry trade and imperfect competition, in Kierzkowski H. (ed.): Protection and competition in international trade, Oxford: Basil Blackwell, 142-161. 
Feenstra, R. C. (1994). New product varieties and the measurement of international prices. American Economic Review, 84, 157-177.

Feenstra, R. C. \& Markusen, G. (1994). Accounting for growth with new inputs. International Economic Review, 35, 429-447.

Feenstra, R. C., Markusen, J. M. \& Zeile, W. (1992). Accounting for Growth with New Inputs: Theory and Evidence. American Economic Review, Papers \& Proceedings, 82(2), 415-21.

Filippini, L. \& Martini, G. (2002). Vertical differentiation and innovation adoption, Mimeo.

Finger, J. M. (1975). Trade Overlap and Intra-Industry Trade. Economic-Inquiry, 13(4), 581-89.

Fontagné, L. \& Freudenberg, M. (1997). Intra-industry trade: Methodological issues reconsidered, document de travail CEPII, $\mathrm{n}^{\circ}$. 97-01, January.

Fontagné, L., Freudenberg, M. \& Peridy, N. (1998). Intra-industry trade and the simple market: Quality matters, CEPR Discussion Paper, $\mathrm{n}^{\circ} .1959$.

Freudenberg, M. \& Lemoine, F. (1999). Central and eastern European countries in the international division of labor in Europe'-annexes, Working Papers, 1999-05c, CEPII, research center.

Frudenberg, M. \& Muller, F. (1992). France et Allemagne : Quelles spécialisations commerciales. Economie Perspective Internationale, 52(4), 7-36.

Fujita, M. \& Thisse, J. F. (1997). Economie géographique, problèmes anciens et novelles perspectives. Annales d'Economie et de Statistique, 45, 37-87.

Funkle, M. \& Ruhwedel, R. (2003). Export variety and economic growth in East European transition economies, BOFIT Discussion Papers, 8, Site Internet: http:/www.bof.fi/bofit.

Funkle, M. \& Ruhwedel, R. (2003). Trade, product variety and welfare: A quantitative assessment for the transition economies in Central and Eastern Europe ", BOFIT Discussion Papers, 17, in: http://www.bof.fi/bofit.

Gambardella, A. \& Torrisi, S. (1998). Does Technological Convergence Imply Convergence in Markets? Evidence from the Electronics Industry. Research Policy, 27, 445-463.

Gollop, F. \& Monahan, J. (1991). A generalized index of diversification: Trends in U.S. manufacturing. The Review of Economics and statistics, 73, 318-330.

Gort, M. (1962). Diversification and integration in American industry, Princeton, University Press.

Grabowski, H. G. (1968). The Determinants of Industrial Research and Development: A Study of the Chemicals, Drug, and Petroleum Industries. Journal of Political Economy, 3, 292-306.

Granstrand, O., Patel, P. \& Pavitt, K. (1997). Multitechnology Corporations. Why They Have Distributed Rather Than Distinctive Core Competencies. California Management Review, 2, 8-25.

Granstrand, 0. (1998). Towards a Theory of the Technology-Based Firm. Research Policy, 27(6), 465-489.

Greenaway, D. \& Milner, C. (1986). The economics of intra-industry Trade, Oxford, Basil Blackwell, 207.

Griliches, Z. (1980). Returns to R\&D expenditures in the private sector, in J. W. Kendrick and B. Vaccara (eds), New Developments in Productivity Measurement and Analysis, Chicago: Chicago University Press.

Gullstrand, J. (2001). Demand Patterns and Vertical Intra-Industry Trade With Special Reference to North-South Trade, CFE Working paper series, 9.

Helpman, E. (1981). International trade in the presence of product differentiation, economies of scale, and monopolistic competition: A chamberlin-Hescher-Ohlin approach. Journal of International Economics, 11, 305-340.

Helpman, E. \& Krugman, P. (1985). Market structure and foreign trade », MIT Press, Cambridge.

Jacob, J. (1969). The economies of cities, Random House. Dans Jacob J. et Los B. (2005): The impact of international technology spillovers and absorptive capacity on productivity growth in Indonesian manufactory firms, Site Internet: www.ggdc.net/conf/wp9-conference/Los.pdf.

Jovanovic, B. (1993). The Diversification of Production, Brookings Papers on Economic Activity. Microeconomics, 1, 197-247.

Hotelling, H. (1929). Stability in competition. Economic Journal, 39, 41-57.

Krugman, P. (1979). Increasing returns, monopolistic competition, and international trade. Journal of International Economics, 9(4), 469-479.

Krugman, P. (1980). Scale economies, product differentiation and the pattern of trade. American Economic Review, 70, 950-959.

Krugman, P. (1981). Intra-industry specialization and the gains from trade. Journal Of political Economy, 89(5), 959-974.

Krugman, P. \& Venables, A. J. (1995). Globalization and the inequality of nations. Quarterly Journal of Economics, 110, 857-880.

Lancaster, K. (1979). Variety, equity, and efficiency, Columbia University Press, New York, 373. 
Lancaster, K. (1980). Intra-industry trade under perfect monopolistic competition. Journal of International Economics, 10(2), 151-175.

Martin, P. \& Ottaviano, G. I. P. (1999). Growing locations: Industry location in a model of endogenous growth. European Economic Review, 43, 281-302.

Morck, R. \& Yeung, B. (2001). Les déterminants économiques de l'innovation, Papers 25, Gouvernement du Canada - Industry Canada \& Gouvernement du Canada -Industry Canada.

Nelson, R. R. (1959). The Simple economics of basic scientific research. Journal of Political Economy, 6(7).

Romer, R. (1990). Endogenous technological change. Journal of political Economy, 98, 71-10.

Romer, R. (1994). New goods, old theory, and the welfare costs of trade restrictions. Journal of Development Economics, 43, 5-38.

Rosenkranz, S. (1996). Simultaneous choice of process and product innovation, CEPR Working Paper, 1321.

Scherer, F. M. (1984). Innovation and Growth, Schumpeterian Perspectives, MIT Press, Cambridge, MA.

Scherer, F. M. (1999). New Perspectives on Economic Growth and Technological Innovation, Brookings Institution Press, Washington.

Shaked, A. \& Sutton, J. (1986). Vertical product differentiation: Some basic themes. American Economic Review, 3, 393-398.

Teece, D. J. (1980). Economies of Scope and the Scope of the Enterprise. Journal of Economic Behavior and Organization, 1(3), 223-247.

Tirole, J. (1988). The Theory of Industrial Organization, MIT Press.

Vega, G. (2000). Does technological diversification promote innovation? An empirical analysis for European firms Site Internet: www.nottingham.ac.uk/economies/ceverhulme/seminars/pdf/GarciaVegapdf.

Venables, A. J. (1996). Equilibrium location of vertically linked industries. International Economic Review, 37, 341-359.

Veuglers, R. (1997). Internal R\&D expenditures and external technology sourcing. Research Policy, 26, 303-315.

Vona, S. (1990). Intra-Industry Trade : A Statistical Artefact or a Real Phenomenon ? Banca nazionale del lavaro. Quarterly review, 43, 383-412.

Wang, J. C. \& Tsai, K. H. (2003). Productivity Growth and R\&D Expenditure in Taiwan's Manufacturing Firms, Working Paper, 9724. Cambridge, Mass.: National Bureau of Economic Research. May.

Weib, P. (2003). Adoption of product and process innovations in differentiated markets: The impact of competition, site Internet: http://129.3.20.41/econ-wp/test/papers/9912/9912049.pdf.

\section{Appendix A}

Choice of the sample: The countries, which are the subject of our analysis, are the principal trade partners of Tunisia. We limited ourselves to the 13 OECD countries that are Germany Belgium, Canada, Denmark, Spain, United States, France, Greece, Italy, Japan, Netherlands, United Kingdom and Sweden.

\section{Appendix B}

\section{Industry categories (ISIC Revision 3 concordance) Source: OECD ANBERD Database 2006 Categories ISIC Revision 3 Descriptions}

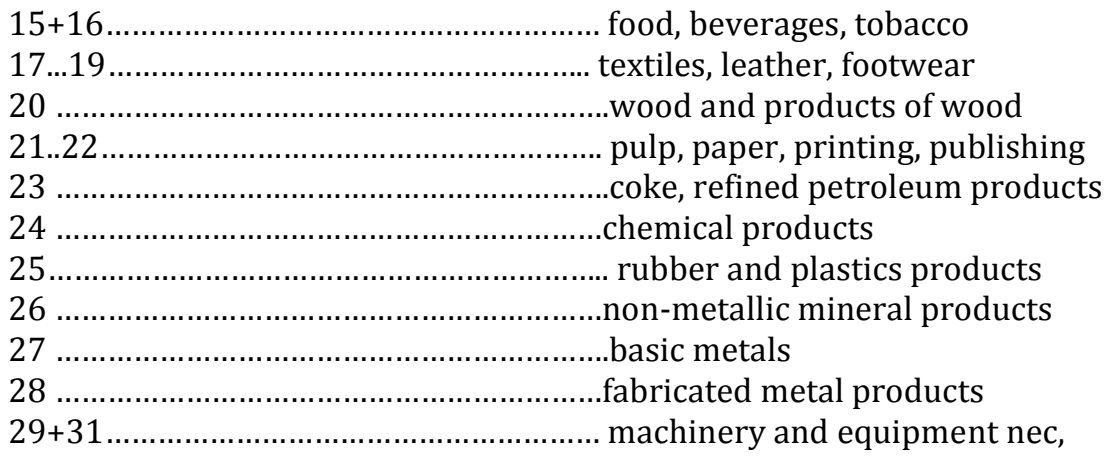

